\title{
TURKISH CHILDREN IN GERMANY LEARNING GRAMMATICAL CATEGORIES IN TURKISH AS A MOTHER TONGUE
}

\author{
Hristo Kyuchukov \\ hkyuchukov@gmail.com \\ University of Silesia in Katowice, Poland \\ Bariş Giray \\ baris-giray@web.de \\ Free University of Berlin, Germany
}

Received December 24, 2017; Revised December 26, 2017; Accepted December 27, 2017

\begin{abstract}
The paper presents and discusses findings from a recent empirical study involving 40 Turkish children aged between 4 and 6 years attending two kindergartens in Berlin in the districts of Wedding and Neukölln. They were tested for their knowledge and comprehension of different grammatical categories in Turkish. Children from Wedding were found to be much better in their knowled ge of the grammatical categories in their mother tongue. The differences are statistically significant $\mathrm{F}(1.32)=6.6258, \mathrm{p}=0.01488(\mathrm{p}<0.05)$. The children from the kind ergarten in Neukölln demonstrated lower results in Turk ish grammar comprehension and thus their achieved literacy in L1.
\end{abstract}

Keywords: Turkish, mother tongue, bilingualism

Кючуков Хрісто, Гірай Баріш. Турецькі діти в Німеччині, які вивчають граматичні категорії турецької мови як рідної.

Анотація. У статті йдеться про результати останнього дослідження із залученням 40 турецьких дітей віком від 4 до 6 років, які відвідують два дитячі садочки в Берліні в районах Веддинг та Нойкьольн. Дітей тестували щодо їхнього знання та розуміння різних граматичних категорій турецької мови. Як з'ясувалося, досліджувані з району Веддинг набагато краще знали граматичні категорії рідної мови. Відмінності були статистично значущими $\mathrm{F}(1.32)=6.6258, \mathrm{p}=0.01488(\mathrm{p}<0.05)$. На противагу, діти із садочку району Нойкьольн продемонстрували гірші результати розуміння граматики турецької, а відтак, гірші показники грамотності рідної мови.

Ключові слова: турецька мова, рідна мова, двомовність.

\section{Introduction}

\subsection{The Turkish Community in Germany}

According to a publication of the Federal Bureau for Migration and Refugees of Germany (Haug et al., 2009), 2.7 million of the 4.3 million Mus lims in Germany are of Turkish decent. The first Turkish Migrants came to Germany in the 1960s after a signed contract between Germany and Turkey - young Turkish men to labor as migrant workers. After WWII, Germany needed cheap labor to help the collapsed economy of the country rebuild. At the beginning their contracts were for two years. But the factories and firms did not want the young Turkish men to leave and they were doing everything possible to ensure their longer stay. Later on a number of the 
young Turkish workers brought their wives or they married German girls and remained in Germany.

The education level of the Turkish migrants is not high. $57 \%$ of those surveyed by Haug et al. had no high school diploma or only attended a lower secondary school (German Hauptschule, from $5^{\text {th }}$ to $9^{\text {th }}$ or $10^{\text {th }}$ grade). The educational trends could be regarded as somewhat optimistic because the proportion of younger Turks in Germany (TiG) without diplomas or only lower secondary Hauptschule schooling has decreased to $45 \%$. Over two-thirds also indicate that they speak better Turkish than German (Haug et al., 2009)

Because the age distribution of the Turkish population is overwhelmingly skewed towards the young, Turkish functions as a peer group vernacular, especially in urban settings. (Gogolin, 2002). Turkish words also become intertwined with German phrases, hybridization: "Komm her," meaning "come here," has acquired the Turkish suffix "lan," meaning man. This becomes "Komm her, lan," or "Come here, man," (Horrocks and Kolinsky, 1996).

An occasionally imperfect knowledge of both languages, combined with a tendency to switch languages situationally, leads to Halbsprachigkeit, or semilingualism (Horrocks, 2002). To outsiders who do not speak both languages, this can be aggravating and seem like semi-competence, but others see it as providing a freedom of choice not available to monolingual speakers. Additionally, the standard German term for an immigrant is der Migrant, which translates most literally to migrant. Though they may have been in Germany for generations, Turks are reminded by German rhetoric that they have to go home again - they are and somehow remain migrants and guest workers (Horrocks and Kolinsky, 1996).

Bagdoshvili (2010) says that preschool education is very important for integration of migrant children in Germany, especially for those whose mother tongue is not German and whose parents have no knowledge of German. For such children it appears that kindergarten is the only place where they have possibility to learn German before they enter school, as their parents have no knowledge of German themselves, and without attending kindergartens and without learning the basics of German, migrant children are not able to deal successfully with the school program. Of the migrant children who attended kindergarten, $51.4 \%$ succeeded in entering lower (Hauptschule) or higher secondary school, but only $21.3 \%$ of the children who did not attend kindergarten reached the same level. By contrast, some kindergartens and schools are becoming segregated, institutions where only migrant children attend. Cummins (2016) discusses the relationship between intercultural education and academic achievement among students from socially marginalized communities. Intercultural education is conceptualized as including a focus both on generating understanding and respect for diverse cultures. Socially marginalized communities experience social exclusion and discrimination, often over generations. Many German parents do not allow their children to attend kindergartens and schools with predominantly migrant children. In such in effect segregated situations, 
the migrant children have no possibilities for school-based communication with children who have German as a native language.

\subsection{Research on learning Turkish as L1}

An adequate acquisition of the official language German seems to still be a huge obstacle for a preponderant segment of Turkish-speaking children living in Berlin. Several theories attempt to explain the reasons for this situation, persisting not only in Germany. In this paper we focus on the mother-tongue and its importance for acquisition and learning additional languages, especially the official language of the host country.

Although the Turkish children live in a multilingual and multicultural environment in Germany, there is no mother-tongue or bilingual program generally available in the pre-school phase. Contact with the mother-tongue is restricted to the home and often the neighborhood environment.

Turkish mother tongue education in Berlin kindergartens is not integrated in the regular curriculum. The kindergartens do not value Turkish in the learning contexts, even though there is a large Turkish community in Berlin. When Turkish instruction is provided decided individually by the kindergartens themselves, it tends to be limited in number of lessons and pedagogical quality. There is no idea or conception regarding the mother tongue as a resource for attaining better competence in the second language, in this case German.

In the European Charter on Regional and Minority Languages, there is an agreement aiming to protect European minority languages and their sustainable facilitation. Germany is one of the first countries that signed it. But under so-called protected languages, Turkish and Russian are excluded. They have no claim to such legitimation for 'protection' by the community and schools, although they more speakers in contrast to languages such as Danish and Sorbian. (Schmitz and Olfert, 2013:208)

Considering multilingual children, it is important not to lose sight of the influential role of their mother-tongue in cognitive development. It has a key empirically demonstrable impact on the social and personal development of a child (Cummins, 2001:17). Children who gain an adequate mother-tongue education or sufficient mother-tongue language input in their early childhood "develop stronger literacy abilities" in the school language (Cummins, 2001:17). But it is not just important to provide a mother tongue education or bilingual learning programs in the kindergarten. Also requisite are efforts to support and "advise parents and other caregivers spending time with their children and tell stories or discuss issues with them," which are preconditions preparing the children for learning the school language and achieving success at school (Cummins, $2001: 17$ ). Cummins notes that in such bilingual education, two languages are "interdependent and "nurture each other when the educational environment creates the requirements" for the children. "Well-implemented bilingual programs can promote literacy and subject matter knowledge in a minority language without any negative effects on children's 
development in the majority language." Learning the home language (minority language) not only impacts on the cultural and personal identification which makes easier "identifying with the mainstream culture and learning the mainstream language" (Cummins, 2001:16) It also helps by "learning concepts and intellectual skills that are equally relevant to their ability to function in the majority language" (Cummins, 2001:18). Developing literacy in both or more languages enable the children to "compare and contrast two language systems," meaning that they have access to a greater range of reality interpretation (Cummins, 2001:17). Bilingual children quickly acquire conversational skills in the majority languages (Cummins, 2001, p. 19) and can easily and rapidly learn to participate in the majority society.

There are "strong affirmative messages about value of knowing additional languages and the fact that bilingualism is an important linguistic and intellectual accomplishment" (Cummins, 2001:19). For example, such children have the ability to gain informational access to different sources in different languages. The preschool years are important not just for socialization and the development of personality and character-forming process. This period also includes the critical phase which is important for the foundation of mother-tongue skills, providing the basis for future success both in the mother tongue language as well for secondlanguage acquisition and other languages that may be learned.

According to Yazici, Ilter \& Glover (2010), there is a clear relation between mother-tongue competence and reading readiness. A rich lexicon in the mother tongue leads to easier literacy achievement (Yazici, 1999). But to benefit fully from education in the second language providing more opportunities for using the mother tongue must be the aim, entailing a need toraise levels of mother-tongue competence.

Citing Cummins (2001), Ileri (2000) and Saracho (1983), Yazici et al. (2010) argue that pre-school children should use their mother tongue, which is needed to support the second language in home and school. Parents should help the children improve their native language skills. Findings also reflect negative effects on self-esteem which may lead to disharmony between the school and home cultures. Parental reports can exaggerate the amount of mother tongue use, as noted by Tannenbaum (2003), so the figures may show a higher level of mother- tongue use than is actually the case.

Cakir (2002) investigates how the second and third generation Turkish immigrants in Germany learn their first language (L1), and how their L1 knowledge contributes to their attempts to adjust to the society they live in. The author explores the relationship between acculturation and first \& second language teaching in Germany, the correlation between L1 development and academic achievement, the external factors affecting L1 development and social adjustment.

In a study with primary school Turkish children, Ozagac (2005) discovered that:

$.50 \%$ of the children had no or poor German language skills

$.53 \%$ of the children had no or poor active language skills.

$.74 \%$ of the children attended the kindergarten.

$.26 \%$ of the children did not attend the kindergarten. 
. $63 \%$ of the children learned German during kindergarten.

In primary classes, the children have the following difficulties:

. $37 \%$ of the children have difficulties reading German.

- $46 \%$ of the children have difficulties writing in German

$.50 \%$ of the children have difficulties solving math problems

. $41 \%$ of children have difficulties retelling math problems.

Treffers-Daller et al. (2007), comparing the complexity of the syntax in Turkish of Turkish-German bilinguals and monolinguals, noted that the monolinguals have much better levels of syntax complexity syntax than the bilinguals. Johnston (2015) says that educators and policy-makers have often ignored preschoolers whose language seems to be lagging behind development in other areas, arguing that such children are "just a bit late" in talking. The research evidence suggests instead that language acquisition should be treated as an important barometer of success in complex integrative tasks.

According to Skutnabb-Kangas (2005), literacy is achieved over time as indicated below:

Table 1

\begin{tabular}{|l|l|l|}
\hline \multirow{2}{*}{ Degree/type of literacy achieved } & \multicolumn{2}{|c|}{$\begin{array}{c}\text { Number of years of formal } \\
\text { education, if the teaching is in }\end{array}$} \\
\cline { 2 - 3 } & \multicolumn{1}{|c|}{$\begin{array}{c}\text { the mother } \\
\text { tongue }\end{array}$} & \multicolumn{1}{c|}{$\begin{array}{c}\text { a foreign } \\
\text { language }\end{array}$} \\
\hline A. Technical skill to decode text & A. 1-2 years & $\begin{array}{l}1-2+2=3-4 \\
\text { years }\end{array}$ \\
\hline B. Lasting "technical" literacy & B. 4-6 years & $\begin{array}{l}4-6+4-5=8- \\
11 \\
\text { years }\end{array}$ \\
\hline $\begin{array}{l}\text { C. Using basic literacy for further education } \\
\text { and as a member of civil society }\end{array}$ & $\begin{array}{l}\text { C. minimally } 8-9 \\
\text { years }\end{array}$ & $\begin{array}{l}8-9+4-5=12- \\
14 \\
\text { years }\end{array}$ \\
\hline $\begin{array}{l}\text { D. Using literacy (including computer } \\
\text { literacy) for full participation in the labour } \\
\text { market and society }\end{array}$ & $\begin{array}{l}\text { D. minimally } 12 \\
\text { years }\end{array}$ & $\begin{array}{l}12+4-5=16- \\
17 \\
\text { years }\end{array}$ \\
\hline
\end{tabular}

\section{Methods}

The study involved 40 Turkish children between 4-6 years old attend ing two kindergartens in Berlin (in Wedding and Neukölln)

The children were divided into two age groups:

-3;6-4;5 years old - 20 children (10 from each kindergarten)

•4;6-5;6 years old - 20 children (10 from each kindergarten) 
The children were tested in Turkish between November 2016 and January 2017. The test used in the study is adapted from English and standardized for Turkish: Test of Early Language Development $-3^{\text {rd }}$ ed. (TELD-3) (Selcuk and Topbas, 2014). The test has two parts - comprehension and production of different grammatical categories.

Here are some examples from the test:
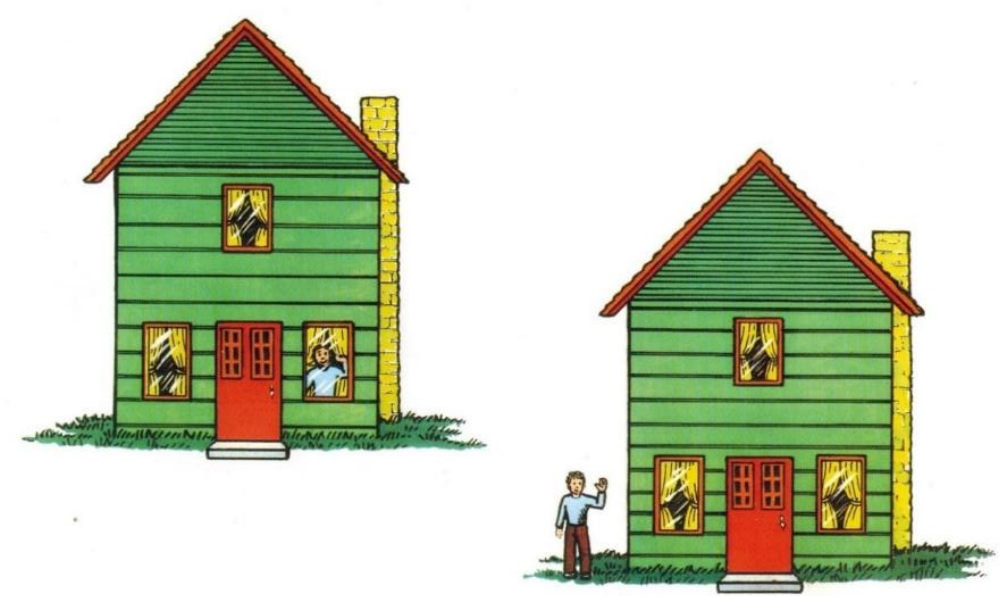

AA 10

Fig. 1. Prepositions
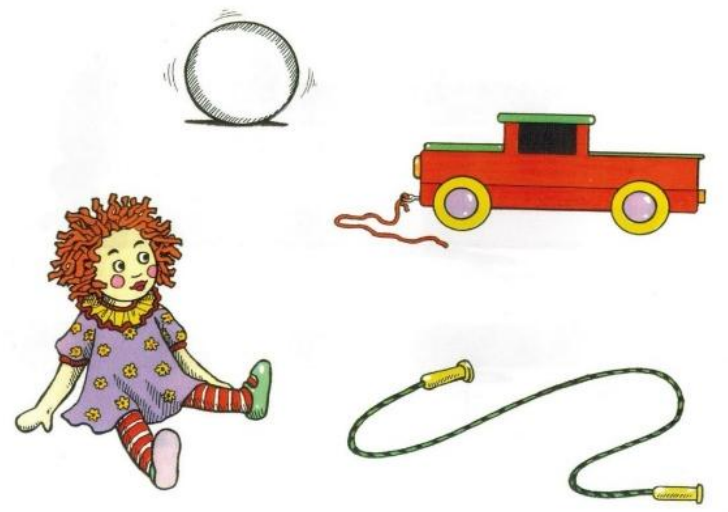

Ai 4

Fig. 2. Abstract nouns 


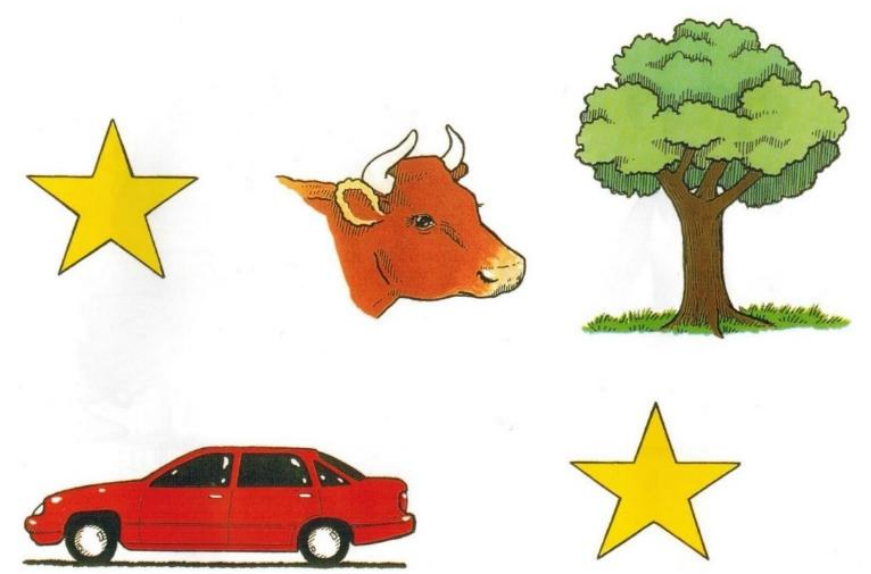

BA 6

Fig. 3. Adjectives
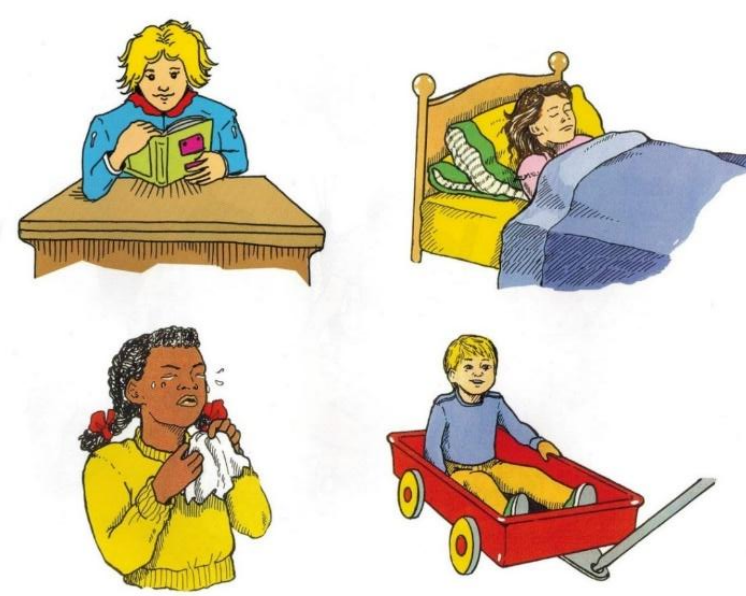

Bi 3

Fig. 4. Verbs 


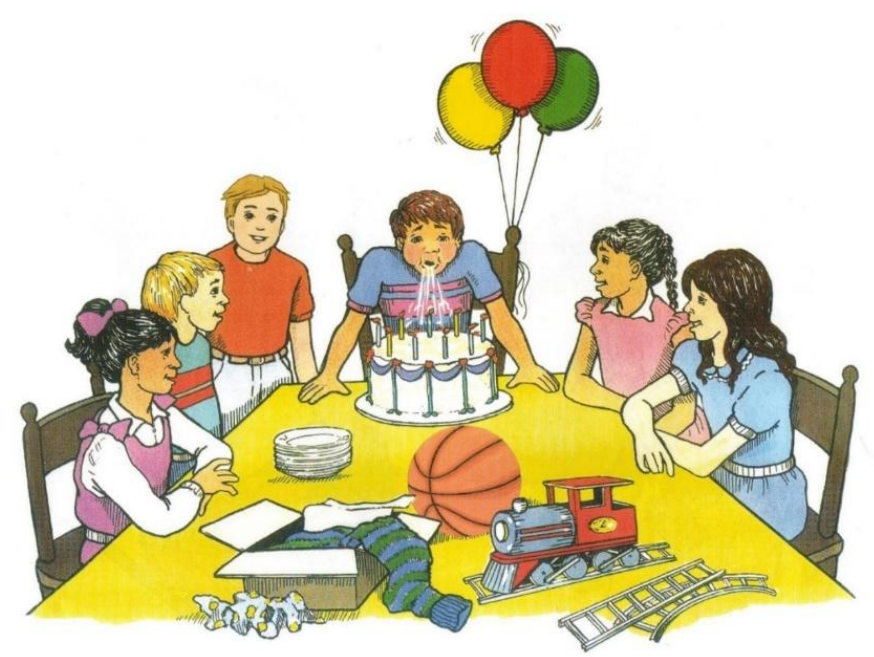

Fig. 5. Narratives comprehension

\section{Results}

\subsection{Comprehension}

The children from both age groups and from both locations show the same degree of comprehension of the grammatical categories. There are no statistically significant differences between the age groups. They understand equally well the grammatical categories and this is shown in Figure 6.

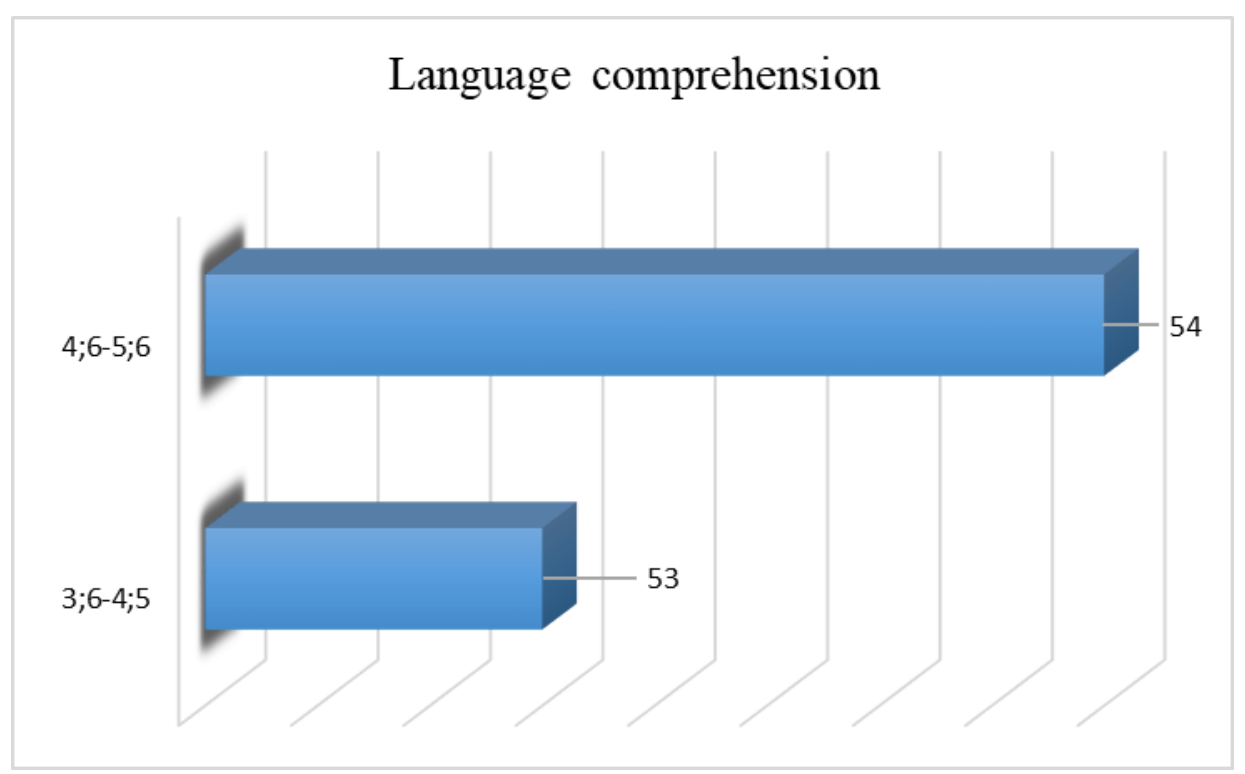

Fig. 6. Results from the Language Comprehension Test

\subsection{Language production}

Figure 7 shows the results of the children by age groups. The differences between the groups are statistically significant. The older children have better 
knowledge of the grammatical categories than the younger children $F(1.16)=6$. $3163, \mathrm{p}=0.02305(\mathrm{p}<0.05)$

Figure 7. Language Production by Age Groups

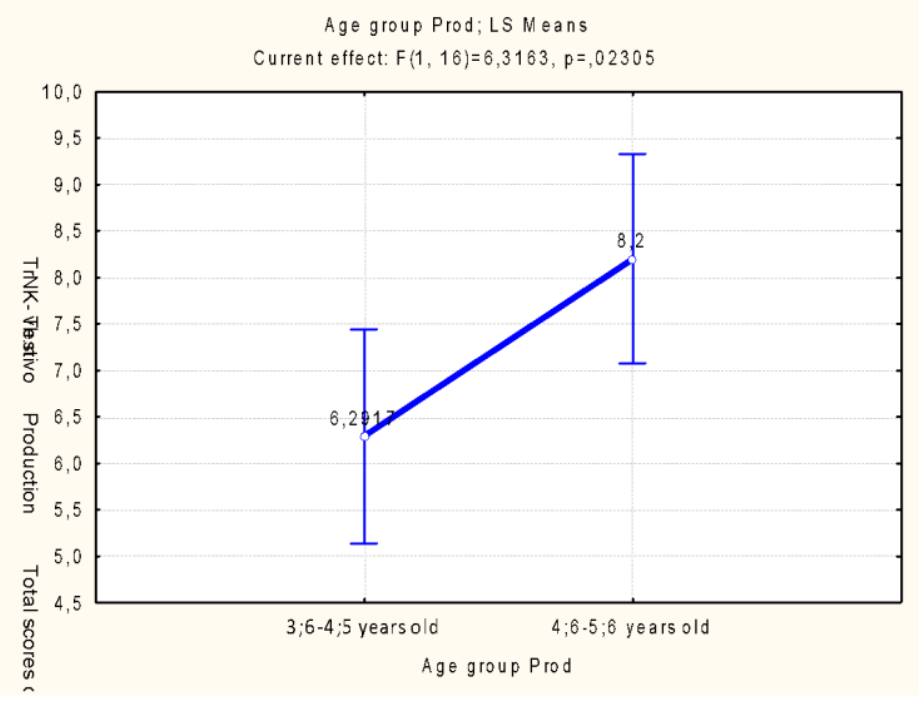

When we compare the results of the children according to the location of the kindergarten, we see that the children from Wedding are much better in their knowledge of the grammatical categories in their mother tongue. The differences are statistically significant $F(1,32)=6.6258, p=0.01488(p<0.05)$. The children from Neukölln show lower results in Turkish. We discuss below what the possible reason may be for such results and what factors influence the children's knowledge of their mother tongue. The differences between the children from both locations are shown in Figure 8.

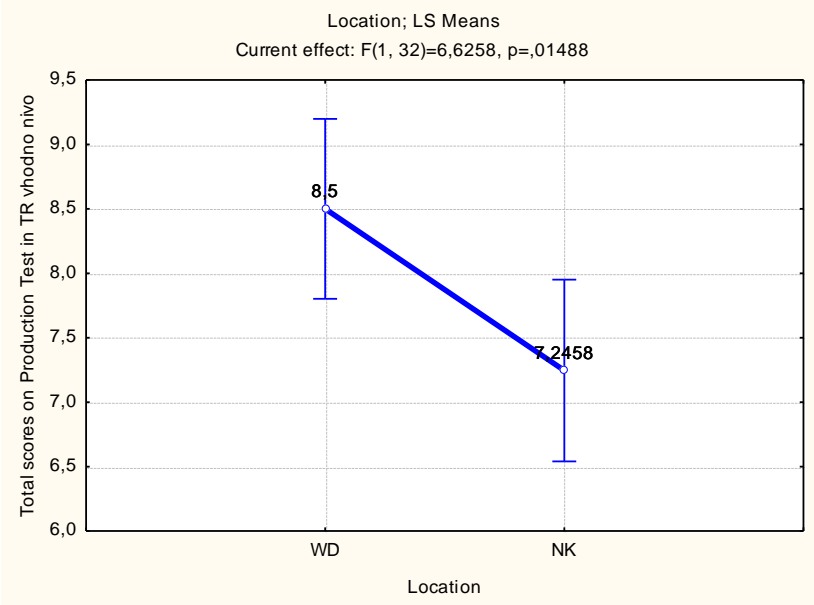

Fig. 8. Language production by location 
What is the interaction between the factors age and location and is the interaction statistically significant? This is shown in Figure 9.

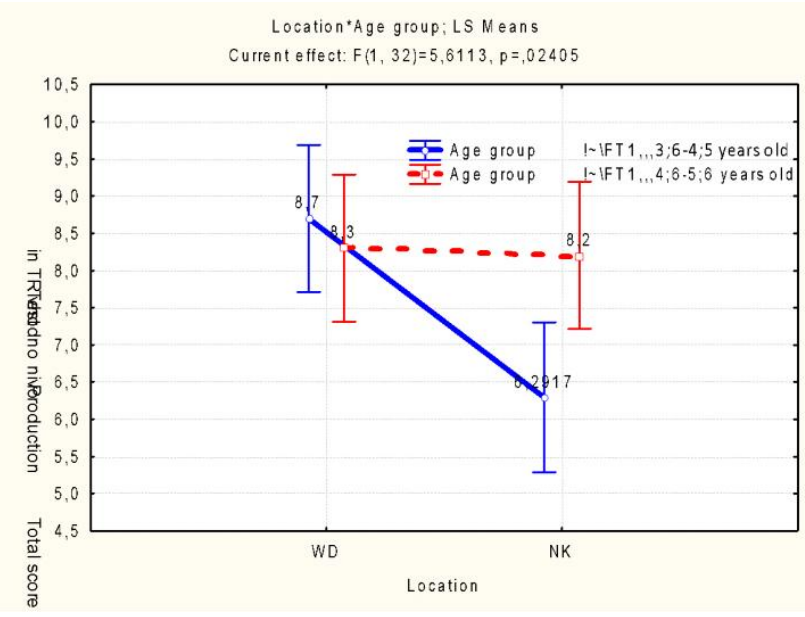

Fig. 9. Interaction between the Factors Age and Location

As can be seen from Figure 9, the interaction between the factors is statistically significant $F(1.32)=5.6113, p=0.02405(p<0.05)$. The results of the children from both groups in Wedding do not show statistically significant differences. The children know all the grammatical categories. The only problem which the children from the younger group have is with the abstract nouns and with production of the narrative in Turkish. However, the older children have a very good knowledge of the grammatical categories.

The children from Neukölln have lower results. There are no differences between the older children form Wedding and Neukölln, but there are significant differences between the children from the younger and older groups.

\section{Discussion and Conclusion}

What are the factors influencing the children's knowledge of their mother tongue?

All the children in the study come from middle-class families. Their parents in most cases try to speak with the children in German only, thinking that in this way they help them to be prepared for school. But their German very often is not good enough. On the other hand, the children in the kindergartens in Neukölln do not get permission from the teachers to talk in Turkish among themselves. In most cases the teachers also come from a Turkish background, but they still do not allow the children to use their mother tongue at play or in other activities.

The kindergarten in Wedding encourages the children to speak Turkish and at the same time the kindergarten organizes the children for receipt of once-a-week lessons in Turkish. The kindergarten also encourages the parents to talk to their children in Turkish in their home environments, to read books in Turkish and to play in Turkish with them. In this way the children acquire a much better knowledge in their mother tongue. 
The situation in the kindergarten in Neukölln differs. There the teachers do not allow the children to speak Turkish among themselves and there is no such support like in the kindergarten in Wedding. The results of the children from Neukölln show notable statistical differences between the two groups. This suggests that more research is needed on whether children encouraged to use their L1 at school, in play and also read at home in their L1 develop a significantly better grasp of certain grammatical categories..

\section{References}

Bagdoshvili, S. (2010) Turkish Migrants in Germany. Unpublished MA Thesis. Tbilisi: Institute of European Studies.

Barac, R. Bialystok, E. (2012) Bilingual effects on cognitive and linguistic development: role of language, cultural background, and education. Child Development, 83(2), 413-422.

Çakir, M. (2002) The use of Turkish as the mother tongue in multicultural settings in Germany. Anadolu University Journal of Social Sciences, 2(1), 39-58

Cummins, J. (2001). Bilingual children's mother tongue: Why is it important for education? Rights and responsibilities of educators of bilingual-bicultural children. In: Making a Difference in the Lives of Bilingual-Bicultural Learners, (pp. 15-20). L.D. Soto, ed. New York: Peter Lang.

Cummins, J. (2016) Intercultural education and academic achievement: a fraimwork for school based polic ies in multilingual schools. Intercultural Education, 26(6), 455-468.

Haug, S. et al. (2009) Muslimisches Leben in Deutschland. Nurnberg.

Horrocks, D. and Kolinsky, E. (1996) Turkish Culture in German Society Today. Oxford: Berghahn Books.

Johnston, J. (2015) Factors that influence language development. In: Encyclopedia of Early childhood development [online], Tremblay, R. E., Boivin, M., Peters R. De V., (eds.). Retrieved from: http:/www.child-encyclopedia.com/language-development-and-literacy/accordingexperts/factors-influence-language-development.

Schmitz, Anke and Olfert Helena (2013): Minderheitssprachen im deutschen Schulwesen - Eine Analyse der Implementierung allochthoner und autochthoner Sprachen. Zeitschrift für Fremdsprachenforschung, 24(2), 203-227.

Skutnabb-Kangas (2005) Skutnabb-Kangas, Tove (2005). Linguistic Genocide. In: Encyclopedia of Genocide and Crimes Against Humanity, 3 Volumes, (pp. 653-654). Shelton, D. (ed.). New York: Macmillan Reference, USA.

Treffers-Daller J., Sumru Özsoy, A., Roeland van Houtet, R. (2007) (In)Complete acquisition of Turk ish among Turkish German bilinguals in Germany and Turkey: An analysis of complex embeddings in narratives. The International Journal of Bilingual Education and Bilingualism, 10(3), 248-276.

Yazıc1, Z. (1999). Almanya ve Turkiye'de Anaokuluna Devam Eden 60-76 Aylar Arasindaki Turk Cocuklarının Dil Geli' imi ile Okuma Olgunluǧu Arasındakillisk inin Incelenmesi [Investigation of connections between language development and reading readiness ofTurkish nursery school children aged 60-76 months in Germany and Turkey]. Ph.D. thesis, Gazi University.

Yazıc1, Z., İlter, B., \& Glover, P. (2010). How bilingual is bilingual? Mother-tongue proficiency and learning through a second language. International Journal of Early Years Education, 18(3), 259-268. 